\title{
Livelihoods as social practices - re-energising livelihoods research with Bourdieu's theory of practice
}

\author{
P. Sakdapolrak \\ Geographisches Institut, Rheinische Friedrich-Wilhelms-Universität Bonn, Meckenheimer Allee 166, 53115 \\ Bonn, Germany \\ Correspondence to: P. Sakdapolrak (psakdapo@uni-bonn.de)
}

Received: 24 August 2012 - Revised: 2 November 2013 - Accepted: 18 November 2013 - Published: 3 April 2014

\begin{abstract}
The persisting problem of poverty in the global south, since the 1990s, has been increasingly analysed and tackled from the perspective of the poor themselves. The shift of view point from a structurally oriented perspective to a more actor-oriented view was closely related to the concept of livelihoods, which put strong emphasis on people-centredness, and examined the coping and survival strategies of people at risk. Livelihoods analysis has been widely applied by research scholars as well as development practitioners since the 1990s, but the drawbacks and pitfalls of the approach have become more and more obvious with its continued application. The approach has been criticised for its imbalanced consideration of the structure-agency relation, narrow focus on the household as a unit of analysis, narrow and non-embedded understanding of assets, and negligence of spatial and temporal dynamics. The livelihoods perspective is at a crossroads. Several scholars have drawn on Bourdieu's theory of practice to overcome the identified challenges. This article seeks to bring together these insights and show how a Bourdieusian perspective can inform and contribute to the advancements in livelihoods research.
\end{abstract}

\section{Introduction}

The persistent problem of poverty in the global south, since the 1990s, has increasingly been analysed and tackled by scholars, as well as policymakers, from the perspective of the poor themselves (see e.g. Kaag et al., 2004:49-51; Scoones, 2009:173) ${ }^{1}$. The shift of viewpoint from a structurally oriented perspective, which dominated the 1970s and 1980s, to a more actor-oriented point of view was closely linked with the concept of livelihoods. Livelihoods research focuses on the actualities of the lives of members of poor and vulnerable groups in an attempt to determine how these groups make their living in the context of risk and stress (Bohle, 2001). Since the 1990s, however, the Department of International Development (DFID), in cooperation with Institute for Development Studies (IDS) in Sussex, England, have synthesised the various insights from these fields to form

\footnotetext{
${ }^{1}$ This paper draws on several intensive discussions with my colleague Fabien Nathan, whom I would like to thank for the critical and crucial comments.
}

the sustainable livelihoods framework (SLF), which in the subsequent years has greatly influenced the way researchers and policy makers have implemented livelihoods analysis (Scoones, 2009:176-181). Although widely applied, this mainstream livelihoods research has also found a substantial number of critics (Krüger, 2003:11-14; Prowse, 2010:219222 ). During the past few years an increasing number of researchers have applied Bourdieu's theory of practice in livelihoods research (see e.g. de Haan and Zoomers, 2005; Dörfler et al., 2003; Etzold, 2013; Obrist et al., 2010; Sakdapolrak, 2010; Thieme, 2008; van Dijk, 2011). This article aims to synthesise insights from these contributions and explore the ways in which the analytical tools provided by Pierre Bourdieu can help enhance livelihoods analysis. My central argument is that Bourdieu's social theory offers a way to overcome the limitations of mainstream livelihoods research and paves the way for a more critical view by recognising the role of power and politics. While Bourdieu's perspective challenges the research practice of mainstream livelihoods research and its implications for development practice, 
it does not challenge the existence of livelihoods research as such.

Following the introduction, I will briefly sketch the history of the livelihoods perspective in Sect. 2 and describe the main limitations of mainstream livelihoods analysis (Sect. 3). Section 4 elaborates on the consideration of Bourdieu's theory of practice, examining the dimensions of habitus, field, and capital, and investigates how its use helps to overcome the current limitations of, and thus enhances, livelihoods analysis. The article concludes with a summary of the main arguments and raises open questions to be addressed in the future.

\section{A brief history of the livelihoods perspective}

Livelihoods research, as Solesbury (2003:14-18, see also Kaag et al., 2004:51-53) points out, owes its prominence to the fruitful interplay between scientific research and development policy and practice ${ }^{2}$.

On the academic side, the question of how people make their living was raised comparatively early, and has drawn the attention of scholars from various scientific disciplines. Kaag et al. (2004:51) identifies Polanyi's (1977) work, The Livelihood of Man, as the first theoretical account on livelihoods. It was Polanyi's objective to develop a holistic and human centred, as well as a socially, culturally and historically embedded economic science. In Development Geography at the Crossroads of Livelihood and Globalisation, de Haan and Zoomers (2003:351) trace the forerunner of modern livelihoods research back to Vidal de la Blache's (1911) concept of genres de vie (modes of life). Livelihoods research as understood today began to take shape in the end of the 1980s and was grounded in research work that Scoones (2009:173) characterises as "integrative, locally embedded, cross sectoral and informed by deep field engagement and a commitment to action". It furthermore placed strong emphasis on people-centredness and examined the coping and survival strategies of people at risk (Kaag et al., 2004:52).

On the side of development policy and practice, the focus on livelihoods has grown out of an opposition to and critique of both hegemonic macroeconomic discourse on poverty and development that were dominant during the 1980s. Their deficiencies stressed the need for more people-centred and sustainable approaches (UN, 1987; UNDP, 1990). Based on the understanding of livelihoods as comprising "capabilities, assets [...] and activities required for a means of living" (Chambers and Conway 1992:6), which is informed by Sen's capability approach (Sen, 1985), the influential sustainable livelihoods framework (SLF) (DFID, 1999) was developed on the basis of longstanding cooperation between the Department for International Development (DFID) (DFID, 1999) and Institute for Development Studies (IDS) in Sus-

\footnotetext{
${ }^{2}$ See de Haan and Zoomers (2003), Kaag et al. (2004), Bohle (2009), Scoones (2009) for elaborated and detailed remarks on the history and development of the livelihoods approach.
}

sex, England (Chambers and Conway, 1992; Scoones, 1998). This checklist diagram has become established as the dominant and mainstream approach to livelihoods research.

As de Haan and Zoomers (2005:31) note, DFID, supported by a strong institutional and financial resource base and access to intellectual capacity, plays a dominant role in the livelihoods discussion (see also Scoones, 2009). The SLF not only has been adopted by several donor agencies such as CARE, Oxfam, UNDP and DFID (Carney et al., 1999; Hussein, 2002), but also has fed back into the scientific community (e.g. Fünfgeld, 2007; Sakdapolrak, 2008).

\section{Livelihoods perspective under pressure}

With the wide application of the SLF by scholars and practitioners in various fields since the 1990s, the drawbacks and pitfalls of the mainstream livelihoods research approach have become increasingly obvious. Consequently a substantial amount of criticism has been expressed by various authors (see e.g. Cahn, 2002:4-5; de Haan and Zoomers, 2005:32-44; Dörfler et al., 2003:13-14; Etzold, 2013; Kaag et al., 2004:53-66; King, 2010:298-300; Krüger, 2003:11-14; Prowse, 2010:219-222; Sakdapolrak, 2010:4748; Scoones, 2009:183-190). In this literature I have identified three clusters of critiques that are repeatedly raised, and which pose a challenge to mainstream livelihoods research:

a. imbalanced consideration of the structure-agency relation,

b. lack of a broadened and embedded notion of assets, and

c. poor recognition of spatial and temporal dynamics.

\subsection{Imbalanced consideration of structure-agency relation}

The livelihoods perspective has been criticised for its imbalanced consideration of the structure-agency relation. The livelihoods approach mantra of people-centredness and actor orientation means that livelihoods analysis places a strong emphasis on actors' agency and the objective of understanding how these actors make a living in the context of stress (see e.g. DFID, 1999). Despite the focus on agency, however, explicit reference to a theory that explains people's actions is lacking. Nevertheless, implicitly the livelihoods approach is deeply permeated by a methodological individualism and the notion of rational and strategic actors who use their assets in order to reach clear ends and maximise their utilities (van Dijk, 2011:101). This simplistic view not only fails to treat the person as a whole, with his or her "perception and ideas, hopes and fears, norms and values" (Kaag et al., 2004:54) into account, but also fails to consider that not all action can be considered as strategic; that is, as based on conscious or intentional decisions (de Haan and Zoomers, 2005:39). Consequently, the ability of individuals and households to choose 
and select is overemphasised, while the structural constraints that limit such choices are neglected (Prowse, 2010:219).

Furthermore, the people-centredness mantra results in a focus on the household as a unit of analysis. What is explicitly suggested is that household strategies, based on the assets available and influenced in some ill-defined way by institutions, shape the livelihoods outcomes. The subject of change and transformation is thus established as being the household, which thus attracts all the attention of the user of the framework. Households are thereby normally considered as unitary entities, and as such less attention is paid to intrahousehold dynamics and conflicts (Prowse, 2010:219). Additionally, households are mainly considered as independent units and not as embedded in social relations. Even though the livelihoods approach explicitly addresses structural aspects (e.g. through social capital or transforming structures and processes in the SLF) in livelihoods studies, the structural level of power and politics has drawn comparatively little attention (Scoones, 2009:178-180, 182). Structural aspects were marginalised, on ideological grounds, by a "community of practice" strongly influenced by economics, with a instrumental poverty-reduction agenda (Scoones, 2009: 180). The disregard of the role of power and politics is further reinforced by fact that the SLF does not give any direction or explanation of how structural aspects such as institutions and policies influence livelihoods, or of how livelihoods influence the structural level.

\subsection{Lack of a broadened and embedded notion of assets}

The core aspect of the livelihoods approach - the concept of assets - has been criticised as being neither broad enough nor sufficiently embedded. The concept of assets is, in most livelihoods analyses, the main analytical tool with which the livelihoods of people at risk are analysed and explained (see e.g. Moser, 1998:2-5; Rakodi, 1999:316-318). However, the conceptualisation of assets remains unelaborated in several ways: Assets are perceived in a very economistic and materialistic way, which results from an extremely material view of the world (White and Ellison, 2006:13-15). Capital is mostly considered as a stock with which households are endowed and that can be utilised by them in order to pursue their ends. Capital and assets are presented in a substantival manner as objective facts (Wood, 2003:456-458). This actualised view diverts attention away from the question of the genesis and trajectory of assets and that of capital accumulation and neglects the relational, socially embedded and contested nature of assets (Bebbington, 1999:2022; van Dijk, 2011:106-113; Wilshusen, 2012). Non-economical or non-material determinants of people's situations, especially in a social or cultural context, as well as those that deal with the structures of domination, are difficult to grasp using the approach. It is therefore important to take into account people's valuation and understanding of capital beyond the mere material sphere. Bebbington (1999:2022) emphasises that assets are not only means for "instrumental action (making a living)"; assets are additionally a source of "hermeneutic action" (making living meaningful); they also have emancipatory power in that they enable people to challenge the structures within which they make their living (Bebbington, 1999:2022).

\subsection{Poor recognition of spatial and temporal dynamics}

Livelihoods analysis has been criticised as having paid insufficient attention to spatial and temporal dynamics. Regarding spatial dynamics, many authors note that livelihoods are deeply embedded in intensified local-global networks of interaction, and that global processes increasingly have ramifications that affect local livelihoods (see e.g. de Haan and Zoomers, 2003; Etzold and Sakdapolrak, 2012; McDowell and de Haan, 1997; Sakdapolrak, 2008). The analysis of livelihoods must take these cross-scale dynamics and the consequences of connectedness into account. However, as Scoones (2009:187) remarks, the livelihoods perspective has failed to systematically engage with the processes of globalisation. De Haan and Zoomers (2003) and Zoomers and Westen (2011) point to the importance of considering multi-local livelihoods and trans-local developments (see also Greiner and Sakdapolrak, 2013). In a broader perspective, Bebbington and Butterbury (2001:373-375) are calling for more attention to be paid to the embeddedness of livelihoods within both trans-local and trans-national structures, networks and spaces, and examining the effects of this connectedness.

With regard to temporal dynamics, the way in which the livelihoods approach focuses on how people make their living has mainly emphasised people's current situations. Stability, durability, resilience and robustness in times of perturbation have been of central interest (Scoones, 2009:189). Temporal dynamics - the role of history, long-term social change, and socio-ecological transformation - have not been widely acknowledged, and livelihoods analysis has therefore been criticised by authors such as Dörfler et al. (2003:1314) as being static and ahistoric (see also du Toit, 2005). It is important to take these temporal dynamics into account. As Scoones and Wolmer (2002:27) point out, "livelihoods emerge out of past actions and decisions are made within specific historical and agro-ecological conditions, and are constantly shaped by institutions and social arrangements".

Scoones (2009:183) observed that by the end of the first decade of the new millennium, policy and research had shifted the focus away from the livelihoods perspective with its contextual, trans-disciplinary and cross-sectoral insights. The livelihoods perspective, according to Scoones (2009:183), is at a crossroads. In the sphere of policy and practice the approach has lost prominence due to the shortening of institutional and financial support for DFID (Prowse, 2010:220). The conceptual challenges that it faces will be either solved by other approaches, leading to a decline of the livelihoods approach, or be met by a "re-energised" 
(Scoones, 2009:191) livelihoods perspective that rises to the challenge. A decline, as Scoones highlights, will be accompanied by the loss of important insights gained through use of the livelihoods perspective. We have witnessed the damaging consequences of macro-economic oriented policies, such as IMF's structural adjustment programmes, for the most vulnerable in the past, and can observe its revival with similar damaging consequences in the current attempt to solve the dept crisis in southern Europe.

\section{Meeting the challenges with Bourdieu's theory of practice}

In recent years a growing number of scholars have drawn on Pierre Bourdieu's theory of practice, with its central theorems of habitus, capital and field, as a way to meet the conceptual challenges of mainstream livelihoods research some explicitly (see e.g. de Haan, 2005; Dörfler et al., 2003; Sakdapolrak, 2007, 2010; Etzold, 2013; van Dijk, 2011) and some in passing (e.g. Rothfuß, 2006; Deffner, 2010; Mahar, 2010). Livelihoods scholars' affinity for Bourdieu's works might be partly due to his commitment not only to combining empirical and theoretical research but also to remaining practically engaged (Susan and Turner, 2011:xxi). This is a position that many livelihoods scholars are also likely to adopt with regard to their own work. Furthermore, on a general level Bourdieu provides a comprehensive social theory which can address individual weaknesses of the livelihoods framework and at the same time integrate the pieces into a coherent picture. Bourdieu's theory of practice seems to offer a particularly fruitful perspective for tackling the three clusters of critique outlined in the section above. In the following section I will elaborate each point by synthesising and systematising insights from various livelihoods researchers who draw on Bourdieu's theory. In doing so, I highlight the usefulness of Bourdieu's work and its potential for re-energising the critical livelihoods perspective.

\subsection{From rational strategies to livelihood styles and pathways}

Bourdieu's statements regarding habitus and social practices have been taken up by various scholars in order to overcome the simplistic understanding of livelihoods strategies as outcomes of purely rational strategic decisions (de Bruijn and van Dijk, 2005a:5ff.; de Haan and Zoomers, 2005:40ff.; van Dijk, 2011:104). Bourdieu emphasises that the majority of social practices, understood as "set ways of doing and saying" (Schatzki, 2002:72), are pre-reflexive and should be conceived as habitual and routinised actions informed by practical knowledge and an implicit "practical sense" (Bourdieu, 1993:167). Social practices are enacted through actors' habitus, which is a system of deeply inscribed dispositions: an embodied manner of being, seeing, acting and thinking; a schema of perception, conception and action (Bourdieu,
2002:43). As an evolving product of socialisation, habitus both structures and shapes social practices, while leaving room for improvisation, creativity and contingence. Structured by actors' social positions, habitus is also the expression and the result of a constellation of a group of actors within the space of inequality (Bourdieu, 1999:279).

How does the concept of habitus and human action briefly sketched above enable a better understanding of livelihoods?

Firstly, through the adoption of a Bourdieusian perspective the "logic of practice" (Bourdieu, 1993:147-179) of people's livelihoods is emphasised, and, as such, attention is given to the inherent rationalities of social practices. Nathan (2008), for example, studies risk perception as a social practice, and argues that people perform "risk perception strategies" which are mediated through habitus, and this leads to an "adaptation of expectations to opportunities". In his study on the livelihoods of urban poor living in slums on the hill slopes of $\mathrm{La}$ Paz under conditions of extreme exposure to the risk of landslides, he explains how people's decisions to live in this risky environment is linked to their risk perception, which is itself structured by their subaltern position within the society. The recognition of the logic of practice helps to better understand people's decision and choices; in this case, for example, why people expose themselves to hazards, whether they actually perceive the hazard they are exposed to, and whether or not they take protective measures.

Secondly, the notion of social practices and habitus, as Staples (2007b) remarks, helps to overcome the tension between constraint and creativity, between structure and agency, by highlighting the space in which marginalised people make meaningful choices without losing sight of the causal structure of marginalisation. In this context de Haan and Zoomers (2005:40) suggest the term "style" as a way to operationalise a habitus-informed understanding of livelihoods: through style, the character of particular livelihoods as distinctive features of groups sharing specific social positions, cultural repertoire, knowledge, interests, and prospects, is emphasised. As such livelihoods are embedded in social relations and linked to broader social structures such as institutions or markets, which may facilitate access to certain livelihoods opportunities but may also constrain the availability of others. Livelihoods are at the same time rooted in and shaped by actors' embodied dispositions, their specific way of perceiving and valuing the world, which explains, for example, why some opportunities are not even considered by some groups. The dynamic interplay which constitutes livelihood styles is illustrated in Staples' (2007a) analysis of the social practices of begging. In his case study on a group of leper beggars from South India, who regularly migrate to Indian metropolitan cities to perform their livelihood - begging - he vividly illustrates how this extreme marginalised group positively utilise the embodied social structure and stigma by which they are oppressed as a route to self-respect and livelihoods security that is otherwise denied to them. 
Thirdly, habitus, as the evolving bodily inscription of socialisation and collective history which is both shaped by and shapes the social and physical environment, challenges the notion of discrete and independent rational decisions and strategies adopted by mainstream livelihoods studies. The concept of livelihoods "pathways", as proposed by de Bruijn and van Dijk (2005a:7ff.; see also Scoones and Wolmer, 2002:195; de Haan and Zoomers, 2005:40-43), recognises that decisions and strategies are rooted in past experiences, learning processes, and personal and collective history. Through the notion of livelihoods pathways, the temporal dynamic of livelihoods is recognised as an iterative process (de Haan and Zoomers, 2005:41-42). De Bruijn and van Dijk (2005a:11) point out that as the habitus of different groups are shaped by different social and physical conditions over time, people facing the same set of conditions may follow very distinctive pathways. Thus, as they elaborate further, variations of coping and adaptation need not be based on synchronic features such as endowment with assets alone, but are also rooted in collective histories inscribed in their habitus. De Bruijn and van Dijk (2005b) make the case for pathways analysis in their research on the livelihoods of Fulbe pastoralists in central Mali. The case study shows how the specific ways in which different groups of Fulbe cope, adapt and mitigate the impact of environmental stress are outcomes of an unfolding process in which personal and collective history is a crucial explanatory factor.

To sum up, in the above section I have highlighted how various authors have drawn on Bourdieu to advance an otherwise rather simplistic understanding of livelihoods strategies. A Bourdieusian approach emphasises the inherent rationalities of human action and draws attention to its social embeddedness and path-dependent character. In employing such a perspective, the analysis of livelihoods is able to capture in a more realistic way the dynamic and multi-dimensional nature of the way in which people make their living.

\subsection{From isolated and neutral to embedded and politicised livelihoods}

One of the main criticisms of the application of the livelihoods approach is its negligence of the broader social and economic structures and power relations that influence individuals and households in their struggle to make a living (Obrist et al., 2010; van Dijk, 2011). Critics point out that livelihoods are never neutral: they both shape and are shaped by processes of inclusion and exclusion, and are embedded in contested and conflicting arenas (de Haan and Zoomers, 2005:34).

Several authors propose Bourdieu's field as an analytical tool by which to embed livelihoods and to facilitate a politicised analysis (see e.g. Didero, 2012; Etzold et al., 2009; Obrist et al., 2010). According to Bourdieu, society is made up of a network of semi-autonomous fields (Bourdieu and Wacquant, 2006: 124ff.). Fields are constituted through power-laden relationships between dominant and subordinated actors, who are unequally endowed with various forms of capital (Bourdieu and Wacquant, 2006:127). These actors struggle and compete over access to goods, resources, positions and power that are at stake. Every field has its own logic, its own rules that, though generally accepted, are also contested by actors within the field (Bourdieu, 1998b:25). These rules simultaneously both enable and constrain their practices and determine the value of their capital in the respective field.

Field analysis helps to map out the livelihoods of vulnerable groups within a web of power-laden social relations, as it requires various guiding questions to be addressed: how is the field constituted? What is at stake in the field? What actors have an interest in the stake of the field? What is the relation of the vulnerable focal actor to other actors in the field? What forms of capital are relevant in the field and how are they distributed and used in the struggle over the stakes? What are the "rules of the game" in the field, which determine the value and exchange rate of capital? By addressing these questions, the embeddedness of livelihoods within a web of power relations can be concretised. Didero's (2012) case study on the livelihoods of the Zabbaleen, a group of waste collectors in Cairo, Egypt, under a changing regulative regime is a case in point. Through a field analysis, she demarcated the field of solid waste management and mapped out various actors at different scales who had an interest in the stake - solid waste. Besides the Zabbaleen, the field of solid waste is constituted through the interactions of various other actors, such as competing groups of informal waste pickers, for whom waste is the immediate means of making a living; the local authorities, who are concerned about public health and the city's image; and the World Bank and IMF, which treat waste collection as an arena in which to pursue a privatisation agenda. Through field analysis, Didero convincingly illustrates that the Zabbaleen, as the most subaltern actors, have only limited influence on the rules of the field, which determine access to and use of solid waste. As such, subsequent changes in the regulative regime, structured by dominant actors, led to the successive marginalisation of the Zabbaleen from their means of making a living.

Didero's study points to the importance of rules governing the relations and exchanges within the field. In doing so, it raises questions about the production and reproduction of institutions as a set of rules governing the relations in the field (Etzold et al., 2012:187). In general, Bourdieu (1998a:48-51) asserts that these rules are also objects of struggle between actors: dominant actors have the power to set rules, which are accepted, but sometime also contested. In this context, Etzold (2013) suggests an analytical differentiation between micro- and macro-level analyses of field regulation: the macro level is dominated by powerful actors and their rule-making power. Through practices of policies and discourses they lay out the dominant frame for the logic of the field. On the micro-level, field relations are governed 
by social norms, informal institutions, and personal relations and negotiations. Micro-political dynamics and practices play an important role on this level (Wilshusen, 2010; Zimmer, 2011). The case for this is made by Etzold (2013) in his study of street food vending and the struggle over the use of public space in Dhaka, Bangladesh. His case study demonstrates on the one hand how the state, through its regulative and discursive power, structures the rules of the game in the field. On the other hand, the study points to the politics of the street and shows how street vendors' lives, their business failures or successes, and their encroachment on public space are all based on negotiated rules and norms in everyday encounters with state representatives.

As fields are not isolated entities, but exist within a set of relations with other fields, and as actors are seldom embedded in only one field, it is crucial to take into account the relations between fields, and the multi-embeddedness of actors within them. Of particular importance, as Bourdieu emphasises, is the relation of sub-fields to the "field of power" (Bourdieu, 1998a:48-51), which is closely linked to the power over the state and the power to determine the rules of the field and the exchange rate between different forms of capital. Etzold's abovementioned case study exemplifies the fundamental influence of the field of power: the 2007/08 coup d'état in Bangladesh, which was accompanied by a shift in the control over the state, resulted in the evictions of thousands of street vendors from public spaces, who were used as scapegoats to demonstrate the new authorities' power.

The recognition of different logics operating in the fields in which actors are embedded, and the frictions that are created by a collision of practices based in diverse logics of practices, highlights another issue that must be considered (Wilshusen, 2008). Focussing on the provision of basic services to slum settlements in Delhi, India, my colleague Anna Zimmer and I (Zimmer and Sakdapolrak, 2013:335-337) show how slum dwellers have gained access to waste water facilities and maintenance by drawing on the conflicting logics of two powerful actors in the field of waste water management: that of the technocratic management field, based on formal regulation, and that of the field of politics, based on the interest in being re-elected.

To sum up, the above remarks highlight how authors successfully draw on Bourdieu's notion of field to decipher what has remained something of a "black box" in livelihoods analysis - the structural embeddedness of livelihoods and the role of power relations in shaping livelihoods opportunities. Field-led livelihoods analysis, as I have outlined, helps to identify relevant actors in the field and map the positions of the focal actors within the field relations. It guides the deconstruction of the field logic, which relates to rules and rule making with regard to both formal and informal rules, and shows the effects of these rules on livelihoods. Through use of Bourdieu's field perspective, livelihoods analysis pays attention to the structural embeddedness of vulnerable actors and addresses questions of politics and power directly.
Livelihoods are interpreted as outcomes of struggle within unequal fields of social relations (Sakdapolrak, 2007).

\subsection{From stocked and static assets to relational and contextualised capital}

The concept of capital plays a central role in Bourdieu's theory of practice (Bourdieu, 1986). While certain conceptual parallels between Bourdieu's "capital" and the "assets" of the livelihoods framework can be identified, Bourdieu's understanding of capital explicitly addresses, as Wilshusen (2012) points out, issues of context, relationality, and power, and thus deeply challenges mainstream non-embedded, ahistoric and static notion of assets in livelihoods studies (see also van Dijk, 2011:106-108).

In social fields that are characterised by struggles over power and positions, according to Bourdieu and Wacquant (2006:128), capital constitutes the objects that are struggled over as well as the means that enable actors to exercise power and influence. In general terms Bourdieu (1986:46) understands capital as "accumulated labour" and "social energy". As such the accumulation and appropriation of capital is related to a productive effort that requires time, and should be conceived of in its temporal dynamic as an evolving historical process. For Bourdieu (1986) the structure of the distribution of capital is an expression of the regularity of the social world. Social actors' relative positions of domination or subordination within this setting are determined by their appropriation of different forms of capital and the way they are valued and perceived in respective social fields. As such, capital also determines the constraints on and success of social practices. With the term "capital", Bourdieu (1997:79) aims to capture the totality of societal exchange processes in order to create a "general science of the economy of practices" (Bourdieu, 1977:183). Bourdieu (1986, 1998a) highlights four fundamental forms of capital, which encompass these various exchange processes: economic, cultural, social and symbolic.

Utilising a Bourdieusian concept of capital for livelihoods research shifts the focus of analysis away from conducting snapshots of households' stocks of capital and draws attention to the dynamic and temporal dimension of capital. Ulrich et al. (2012) for example, illustrate continuity and change in the composition of the capital portfolio of small-scale farming households in semi-arid areas of Kenya over a period of $13 \mathrm{yr}$. While they explicitly refer to Bourdieu's notion of capital, it continues to be treated as a relatively neutral and autonomous additional input for livelihoods analysis. Van Dijk (2011) stresses that a Bourdieusian approach considers appropriated capital as the consequence of power struggles in uneven social fields, and highlights the need to address the questions of how capital is generated, distributed and destroyed. This is exemplified in my case study on slumdwellers' health vulnerability in Chennai, South India (Sakdapolrak 2010:151ff.). I conceptualise the slum-dwellers' 
appropriation of housing capital as the result of subversive practices of appropriation of "no rent land", which is contested and destroyed vis-à-vis the interests of powerful actors such as the city council in their drive to develop the city. My analysis shows how housing capital must be conceived of as a product of power-laden social relations, in which slum dwellers' agency in enhancing and accumulating capital is severely constrained.

The study of the ways in which different forms of capital are exchanged and converted is an important area in which the use of a Bourdieusian perspective broadens the scope of livelihoods research. A case in point is the study of Wilshusen $(2009,2010)$, who draws on Bourdieu to examine capital exchange as a means by which to analyze power relationships over time. His detailed case study on timber-marketing funds and community forestry in southeastern Mexico reveals that through the enactment of social capital in everyday interactions and negotiations, which have created a dynamic web of power relationships, elites within the community were able to divert money from the timbermarketing funds in a way that exacerbated inequalities and so strengthened their dominant position within the community. By focusing on capital and its conversion he directly addresses capital as a mechanism for the perpetuation of unequal power relations. In a similar manner, Thieme and Siegmann (2010) address the role of social capital in migration networks from a gender perspective and highlight how social capital perpetuates the structure of masculine domination and a gender-differentiated pattern of vulnerability.

The alteration of the value of capital within and between fields is another area of investigation for a Bourdieusian capital analysis. As Bourdieu points out, capital does not have an intrinsic value, but rather its value is linked to the logics of fields (Bourdieu and Wacquant, 2006:132). Changing rules in the field can therefore lead to changes in the value of capital. In the case of Didero (2012), a privatisation drive led to the devaluation, or more precisely, the annulment of waste collection licences (institutionalised cultural capital) held by small waste companies, which had used to resell their licenses to the Zabbaleen. The informal ties (social capital) and money (economic capital) of the Zabbaleen, through which they gained access to waste collection, were thus also devalued within the changing field configuration. The fieldspecific value of capital, and its devaluation in changing social fields, is most vividly illustrated in studies on international migration (see e.g. Thieme, 2008; Kelly and Lusis, 2006). A case in point is the work of Bauder (2003) who examines the exclusion of international migrant workers from upper-segment labour markets in Canada through the devaluation of their capital (e.g. institutionalised cultural capital in the form of education certificates) in the social field of the receiving country. These studies point to the rules governing the value and exchange of capital, which determine constraints for livelihood opportunities.
To sum up, a Bourdieusian notion of capital in livelihoods analysis emphasises its dynamic character, viewing it as a result of social struggle in power-laden social relations. Within such a framework, as van Dijk (2011:101) points out, poverty and livelihood insecurity are not interpreted as lack of capital (a condition) but as the absence of, or deprivation of access to, entitlements (a relation).

\section{Outlook - moving ahead in livelihoods research}

After a brief sketch of the origins of the livelihoods perspective and its central features, I have highlighted the main conceptual limitations of mainstream livelihoods studies, which are strongly influenced by the SLF of DFID. Those limitations are (a) imbalanced consideration of structure-agency relations, (b) lack of a broadened and embedded notion of assets, and (c) poor recognition of spatial and temporal dynamics. The central argument of the paper is that Pierre Bourdieu's theory of practice is an analytical tool with which these limitations can be overcome: the Bourdieu-inspired notion of livelihood styles and pathways, which acknowledges the inherent logics of actors, their social embeddedness, and the path dependencies of livelihoods practices, significantly alters the comprehension of livelihoods strategies as strategic actions of rational actors; that Bourdieu's field analysis renders transparent the "black box" of the "transforming structures and processes" of the SLF, and facilitates the inclusion of power relations and structures of domination and subordination into a politicised understanding of livelihoods; and finally that the concept of assets as the main analytical tool in mainstream livelihoods research has been significantly expanded by Bourdieu's power-laden and processual notion of capital.

To conclude, the popularity of livelihoods research has greatly contributed to a better understanding of how marginalised groups make their living under adverse conditions by highlighting their agency and creativity. Through an extensive review of the literature, I have shown that an understanding of livelihoods as social practices facilitates a socially embedded, multi-scalar and dynamic analysis of politicised livelihoods. Through a Bourdieusian perspective, the arena of politics and power is considered "not just context, but a focus of analysis in and of itself" (Scoones, 2009:185). As such, livelihoods appear as a political process with uneven outcomes, in which some gain and others lose (Eriksen and Lind, 2009). The question of the enhancement of the livelihoods of the marginalised and vulnerable, therefore, is changed from a technical to a political one, which challenges existing structures and conditions that produce marginalisation. Bourdieu's theory thus offers a path toward the reenergising of livelihoods research.

As a final point, I want to address two questions that the review have left open: first, as the review has shown, the Bourdieusian-inspired analysis of livelihoods is quite 
removed from the approaches implicitly underlying the SLF. Therefore, the question might be raised as to whether this body of scholarly work should still be considered livelihoods research at all. In my opinion, it should, since the core of the livelihoods approach (see Sect. 2) is not itself challenged by a Bourdieusian analysis. Rather the SLF as a heuristic model of livelihoods has been opened up by an analytical theory which makes statements about how different components of the heuristic model are related to each other. What had previously remained implicitly and ideologically influenced by rational choice theory and neo-liberalism has now been replaced by an alternative, explicit and critical understanding of the social world.

Second, while the work of most of the scholars in this review applies Bourdieu's ideas - whether explicitly or implicitly - to overcome the limitations of mainstream livelihoods research and advance the understanding of livelihoods, those scholars have generally not addressed the question of the limitations of a Bourdieusian approach. In raising this question I will refrain from reiterating the general criticism of Bourdieu's work, as this is not in the scope of this paper (see e.g. King, 2000; Verdes-Leroux, 2001). Nevertheless, I would like to point out one implication of a Bourdieusian-inspired critical livelihoods research, which might be considered by some as a limitation: that is, the relation between research and practice. As has been outlined in Sect. 2, the popularity of the livelihoods approach is the result of a fruitful interplay between scientific research and development policy and practice. The particular interpretation of mainstream livelihoods research has facilitated this link by legitimising an instrumental and apolitical approach in development work (e.g. poverty reduction). How can the results of a critical livelihoods analysis that locates the root causes of vulnerability and insecurity in the fundaments of the society be translated into development policy and practice which has come to favour apolitical and neutral solutions and the stabilisation of the status quo? What are the implications of Bourdieusian livelihoods research for the relation between science and practice? This remains an open question that still needs to be addressed.

Edited by: B. Korf

Reviewed by: four anonymous referees

\section{References}

Bauder, H.: "Brain Abuse", or the Devaluation of Immigrant Labour in Canada, Antipode, 35, 699-717, 2003.

Bebbington, A.: Capitals and capabilities: A framework for analysing peasant viability, rural livelihoods and poverty, World Dev., 27, 2021-2044, 1999.

Bebbington, A. J. and Butterbury, S. P. J.: Transnational livelihoods and landscapes. Political ecologies of globalization, Ecomene, 8 , 369-380, 2001.
Bohle, H.-G.: Neue Ansätze der geographischen Risikoforschung: Ein Analyserahmen zur Bestimmung nachhaltiger Lebenssicherung von Armutsgruppen, Die Erde, 132, 119-140, 2001.

Bohle, H.-G.: Sustainable livelihood security. Evolution and application, in: Facing global environmental change: Environmental, human, energy, food, health and water security concepts, edited by: Brauch, H. G., Grin, J., Mesjaszet, C., Kameri-Mbote, P., Behera, N. C., Chourou, B., and Krummenacher, H., Springer, Berlin, 521-528, 2009.

Bourdieu, P.: The Forms of Capital, in: Handbook of Theory and Research for the Sociology of Education, edited by: Richardson, J., Greenwood Press, New York, 241-258, 1986.

Bourdieu, P.: Sozialer Sinn. Kritik der theoretischen Vernunft, Suhrkamp, Frankfurt am Main, 1993.

Bourdieu, P.: Für einen anderen Begriff von Ökonomie, in: Der Tote packt den Lebenden, Bourdieu, P., Schriften zu Politik \& Kultur 2, Hamburg, 79-100, 1997.

Bourdieu, P.: Praktische Vernunft: zur Theorie des Handelns, Suhrkamp, Frankfurt am Main, 1998a.

Bourdieu, P.: Vom Gebrauch der Wissenschaft. Für eine klinische Soziologie des wissenschaftlichen Feldes, UVK, Konstanz, 1998b.

Bourdieu, P.: Die feinen Unterschiede: Kritik der gesellschaftlichen Urteilskraft, Suhrkamp, Frankfurt, 1999.

Bourdieu, P.: Habitus, in: Habitus: A Sense of Place, edited by: Hillier, J. and Rooksby, E., Ashgate, Burlington, 43-49, 2002.

Bourdieu, P.: Outline of a Theory of Practice, Cambridge University Press Cambridge and New York, 1977.

Bourdieu, P. and Wacquant, L. J. D.: Reflexive Anthropologie, Suhrkamp, Frankfurt am Main, 2006.

Cahn, M.: Sustainable Livelihoods Approach: Concept and Practice - Contesting development: Pathways to better practice: Proceedings of the Third Biennial Conference of the Aotearoa New Zealand International Development Studies Network (DevNet), Aotearoa, 5-7 December 2002, Massey University, Palmerston North, N.Z., 2002.

Carney, D., Drinkwater, M., Rusinow, T., Neefjes, K., Wanmali, S., and Sing, N.: Livelihoods approaches compared: A brief comparison of the livelihoods approaches of the UK Department for International Development (DFID), CARE, Oxfam and the United Nations Development Programme (UNDP), Department for International Development (DFID), London, 1999.

Chambers, R. and Conway, G. R.: Sustainable rural livelihoods: A practical concept for the 21st century, IDS, Discussion Paper, 296, Institute of Development Studies (IDS), Sussex, 1992.

De Bruijn, M. and van Dijk, H.: Introduction: Climate and society in Central and South Mali, in: Sahelian pathways. Climate and society in Central and South Mali, edited by: De Bruijn, M., van Dijk, H., Kaag, M., and van Til, K., African Studies Centre, Leiden, 2005a.

De Bruijn, M. and van Dijk, H.: Moving people: Pathways of Fulbe pastoralists in the Hayre-Seeno area, Central Mali, in: Sahelian pathways. Climate and society in Central and South Mali, edited by: De Bruijn, M., van Dijk, H., Kaag, M., and van Til, K., African Studies Centre, Leiden, 249-279, 2005 b.

De Haan, L.: How to research the changing outlines of African livelihoods, 11th General Assembly of CODESRIA, Maputo, 610 December 2010 African Studies Centre, Leiden, 2005. 
De Haan, L. and Zoomers, A.: Development Geography at the Crossroads of Livelihood and Globalisation, Tijdschrift voor Economische en Sociale Geografie, 94, 350-362, 2003.

De Haan, L. and Zoomers, A.: Exploring the Frontier of Livelihoods Research, Dev. Change, 36, 27-47, 2005.

Deffner, V.: Habitus der Scham. Die soziale Grammatik ungleicher Raumproduktion. Eine sozialgeographische Untersuchung der Alltagswelt Favela in Salvador da Bahia (Brasilien), Geographisches Institut, Universität Passau, Passau, 2010.

DFID: Sustainable Livelihood Guidance Sheets, available upon request to livelihoods@dfid.giv.uk, 1999.

Didero, M.: Cairo's informal waste collectors: a multi-scale and conflict sensitive perspective on sustainable livelihoods, Erdkunde, 66, 27-44, 2012.

Dörfler, T., Graefe, O., and Müller-Mahn, D.: Habitus und Feld: Anregungen für eine Neuorientierung der geographischen Entwicklungsforschung auf der Grundlage von Bourdieus "Theorie der Praxis", Geogr. Helv., 58, 11-23, doi:10.5194/gh-58-112003, 2003.

Du Toit, A.: Poverty Measurement Blues: Some Reflections on the Space for Understanding 'Chronic' and 'Structural' Poverty in South Africa, SSRN Electronic Journal, 1-18, 2005.

Eriksen, S. and Lind, J.: Adaptation as a Political Process: Adjusting to Drought and Conflict in Kenya's Drylands, Environ. Manage., 43, 817-835, 2009.

Etzold, B., Bohle, H.-G., Keck, M., and Zingel, H.-P.: Informality as agency - negotiating food security in Dhaka, Die Erde, 140, 1-22, 2009.

Etzold, B.: The Politics of Street Food. Contested Governance and Vulnerabilities in Dhaka's Field of Street Vending, Megacities and Global Change, 13, Franz Steiner Verlag, Stuttgart, 2013.

Etzold, B. and Sakdapolrak, P.: Globale Arbeit - lokale Verwundbarkeit: Internationale Arbeitsmigration in der geographischen Verwundbarkeitsforschung, in: Migration und Entwicklung aus geographischer Perspektive. - = IMIS-Beiträge 42, edited by: Steinbrink, M. and Geiger, M., Osnabrück, 2012.

Etzold, B., Jülich, S., Keck, M., Sakdapolrak, P., Schmitt, T., and Zimmer, A.: Doing Institutions. A Dialectic Reading of Institutions and Social Practices and its Relevance for Development Geography, Erdkunde, 66, 185-195, 2012.

Fünfgeld, H.: Fishing in muddy waters. Socio-environment relations under the impact of violence in eastern Sri Lanka, Verlag für Entwicklungspolitik, Saarbrücken, 2007.

Greiner, C. and Sakdapolrak, P.: Translocality: Concepts, application and emerging research perspectives, Geography Compass, 7, 373-384, 2013.

Hussein, K.: Livelihoods approaches compared: A multi-agency review of current practice, Department for International Development, London, 2002.

Kaag, M., van Berkel, R., Brons, J., de Bruijn, M., van Dijk, H., de Haan, L., Nooteboom, G. and Zoomers, A.: Ways forward in livelihood research, in: Globalization and development. Themes and concepts in current research, edited by: Kalb, D., Panters, W., and Siebers, H., Kluwer Academic Press, Dordrecht, 49-74, 2004.

Kelly, P. and Lusis, T.: Migration and the transnational habitus: evidence from Canada and the Philippines, Environ. Plann. A 38, 831-847, 2006.
King, A.: Thinking with Bourdieu against Bourdieu: A "Practical" critique of the habitus, Sociological Theory, 18, 417-433, doi:10.1111/0735-2751.00109, 2000.

King, B.: Spatialising livelihoods: resource access and livelihood spaces in South Africa, T. I. Brit. Geogr., 36, 297-313, 2010.

Krüger, F.: Handlungsorientierte Entwicklungsforschung: Trends, Perspektiven, Defizite, Petermann. Geogr. Mitt., 147, 6-15, 2003.

Mahar, C. A.-C.: Reinventing practice in a disenchanted world. Bourdieu and Urban Poverty in Oaxaca, Mexico, University of Texas Press, Austin, 2010.

McDowell, C. and De Haan, A.: Migration and Sustainable Livelihoods: A Critical Review of the Literature, University of Sussex, Institute of Development Studies (IDS), Sussex, 1997.

Moser, C. O. N.: The asset vulnerability framework: Reassessing urban poverty reduction strategies, World Dev., 26, 1-19, 1998.

Nathan, F.: Risk perception, risk management and vulnerability to landslides in the hill slopes in the city of La Paz, Bolivia. A preliminary statement, Disasters, 32, 337-357, 2008.

Obrist, B., Pfeiffer, C., and Henley, R.: Multi-layered social resilience: a new approach in mitigation research, Progress in Development Studies, 10, 283-293, 2010.

Polanyi, K.: The livelihood of man, Academic Press, New York, 1977.

Prowse, M.: Integrating reflexivity into livelihoods research, Progress in Development Studies, 10, 211-231, 2010.

Rakodi, C.: A capital assets framework for analysing household livelihood strategies: Implication for policy, Dev. Policy Rev., 17, 315-342, 1999.

Rothfuss, E.: Hirtenhabitus, ethnotouristisches Feld und kulturelles Kapital: zur Anwendung der "Theorie der Praxis" (Bourdieu) im Entwicklungskontext: Himba-Rindernomaden in Namibia unter dem Einfluss des Tourismus, Geogr. Helv., 61, 32-40, doi:10.5194/gh-61-32-2006, 2006.

Sakdapolrak, P.: Water related health risk, social vulnerability and Pierre Bourdieu, in: Perspectives on Social Vulnerability, edited by: Warner, K., SOURCE 6/2007, Bonn, 50-59, 2007.

Sakdapolrak, P.: Jenseits von "Push and Pull" Internationale Arbeitsmigration als Strategie der Lebenssicherung in Thailand, Int. Asienforum, 39, 81-105, 2008.

Sakdapolrak, P.: Orte und Räume der Health Vulnerability. Bourdieus Theorie der Praxis für die Analyse von Krankheit und Gesundheit in Megaurbanen Slums von Chennai, Südindien, Verlag für Entwicklungspolitik, Saarbrücken, 2010.

Sen, A.: Commodities and Capabilities, Oxford University Press, Oxford, 1985.

Schatzki, T.: The site of the social: a philosophical account of the constitution of social life and change, Penn State University Press, University Park, PA, 2002.

Scoones, J.: Sustainable rural livelihoods: A framework for analysis, Institute of Development Studies (IDS), Brighton, 1998.

Scoones, I.: Livelihoods perspectives and rural development, J. Peasant Stud., 36, 171-196, 2009.

Scoones, I. and Wolmer, W.: Pathways of change in Africa. Crops, Livelstock and Livelihoods in Mali, Ethiopia and Zimbabwe, James Currey, Oxford, 2002.

Solesbury, W.: Sustainable livelihoods: A case study of the evolution of DFID policy, Overseas Development Institute, London, 2003. 
Staples, J.: Begging Questions: Leprosy and Alms Collection in Mumbai, in: Livelihoods at the margins. Surviving the city, edited by: Staples, J., Left Coast Press, Walnut Creek, 163-186, 2007a.

Staples, J.: Introduction: Livelihoods at the margins, in: Livelihoods at the margins. Surviving the city, edited by: Staples, J., Left Coast Press, Walnut Creek, 9-30, 2007b.

Susen, S., and Turner, B. S.: Introduction: Preliminary reflections on the legacy of Pierre Bourdieu, in: The Legacy of Pierre Bourdieu: Critical Essays, edited by: Susen, S. and Turner, B. S., Anthem Press, New York, xiii-xxix, 2011.

Thieme, S.: Sustaining Livelihoods in Multi-local Settings: Possible Theoretical Linkages Between Transnational Migration and Livelihood Studies, Mobilities, 3, 51-71, 2008.

Thieme, S. and Siegmann, K.: Coping on Women's Backs: Social Capital-Vulnerability Links through a Gender Lens, Current Sociology, 58, 719-737, 2010.

Ulrich, A., Ifejika Speranza, C., Roden, P., Kiteme, B., Wiesmann, U., and Nüsser, M.: Small-scale farming in semi-arid areas: Livelihood dynamics between 1997 and 2010 in Laikipia, Kenya, J. Rural Stud., 28, 241-251, 2012.

UN: Report of the World Commission on Environment and Development. Our Common Future, United Nations, New York, 1987.

UNDP: Human Development Report. Concept and measurement of human development, United Nations, New York, 1990.

Van Dijk, T.: Livelihoods, capitals and livelihood trajectories: a more sociological conceptualisation, Progress in Development Studies, 11, 101-117, 2011.

Verdes-Leroux, J.: Deconstructing Pierre Bourdieu: Against sociological terrorism from the left, Algora Publishing, New York, 2001.

Vidal de la Blache, P.: Les genres de vie dans la géographie humaine, Annales de Géographie, 20, 193-212, 1911.
White, S. and Ellison, M.: Wellbeing, livelihoods and resources in social practice, in: Wellbeing in Developing Countries. From Theory to Research, edited by: Gough, I. and McGregor, J. A., Cambridge University Press, Cambridge, 157-175, 2006.

Wilshusen, P. R.: Social process as everyday practice: the micropolitics of community-based conservation and development in southeastern Mexico, Policy Sci., 42, 137-162, 2008.

Wilshusen, P. R.: Shades of social capital: elite persistence and the everyday politics of community forestry in southeastern Mexico, Environ. Plann., 41, 389-406, 2009.

Wilshusen, P. R.: The Receiving End of Reform: Everyday Responses to Neoliberalisation in Southeastern Mexico, Antipode, 42, 767-799, 2010.

Wilshusen, P. R.: Capitalizing Conservation / Development : Misrecognition and the Erasure of Power, in: B. Büscher, Fletcher, R. and Dressler, W. (eds.): Nature ${ }^{\mathrm{TM}}$ Inc? Questioning the Market Panacea in Environmental Policy and Conservation, University of Arizona Press, Tuscon, 2012 (prepress).

Wood, G.: Staying Secure, Staying Poor: The "Faustian Bargain", World Dev., 31, 455-471, 2003.

Zimmer, A.: "Everyday governance of the waste waterscapes. A Foucauldian analysis in Delhi's informal settlements", Ph.D. thesis, Department of Geography, Bonn University, 2011.

Zimmer, A. and Sakdapolrak, P.: The social practices of governing. Viewing waste water governance in Delhi's slums with Foucault and Bourdieu, Environment and Urbanization ASIA, 3, 325-341, 2012.

Zoomers, A. and v. Westen, G.: Introduction: translocal development, development corridors and development chains, Int. Dev. Plann. Rev., 33, 377-388, 2011. 